NBER WORKING PAPER SERIES

\title{
INTERNATIONAL COMPARISONS OF R\&D EXPENDITURE: DOES AN R\&D PPP MAKE A DIFFERENCE?
}

\author{
Sean M. Dougherty \\ Robert Inklaar \\ Robert H. McGuckin \\ Bart van Ark \\ WORKING PAPER 12829 \\ http://www.nber.org/papers/w12829 \\ NATIONAL BUREAU OF ECONOMIC RESEARCH \\ 1050 Massachusetts Avenue \\ Cambridge, MA 02138 \\ January 2007
}

This research is made possible by grant SRS/SES 00-99594 from the National Science Foundation (McGuckin et al., 2004a), and was carried out while the authors were all residing at The Conference Board. The paper was originally prepared for the September 2003 NBER-CRIW Conference in honor of Zvi Griliches, and is forthcoming in Hard-to-Measure Goods and Services: Essays in Honor of Zvi Griliches, Ernst R. Berndt and Charles M. Hulten, Editors, from The University of Chicago Press, Spring 2007. Related work was presented at seminars of the National Academy of the Sciences in Washington, D.C., the OECD Science, Technology, and Industry Directorate in Paris, the NBER-CRIW Summer Institute in Cambridge, MA, The Conference Board's International Innovation Council in Cambridge, U.K., and the meeting of the Canberra II Group on the Measurement of Non-Financial Assets in Voorburg. We received particularly useful comments from Andrew Wyckoff and Dominique Guellec (OECD), Jeffrey Bernstein (Carleton University and NBER) and Ernst Berndt (MIT and NBER). We are deeply saddened that our co-author Robert H. McGuckin passed away in March 2006. His contribution to the economics profession will live on through his extensive published work. The views expressed herein are those of the author(s) and do not necessarily reflect the views of the National Bureau of Economic Research or the authors institutions.

(C) 2007 by Sean M. Dougherty, Robert Inklaar, Robert H. McGuckin, and Bart van Ark. All rights reserved. Short sections of text, not to exceed two paragraphs, may be quoted without explicit permission provided that full credit, including () notice, is given to the source. 
International Comparisons of R\&D Expenditure: Does an R\&D PPP Make a Difference?

Sean M. Dougherty, Robert Inklaar, Robert H. McGuckin, and Bart van Ark

NBER Working Paper No. 12829

January 2007

JEL No. C43, L16, L60, O32, O47

\section{ABSTRACT}

Purchasing power parities (PPPs) for R\&D expenditure in 19 manufacturing industries are developed for France, Germany, Japan, the Netherlands and the United Kingdom relative to the United States for the years 1997 and 1987. These PPPs are based on R\&D input prices for specific cost categories and differ substantially from current practice of comparing R\&D expenditure using GDP PPPs and deflators. After taking into account differences in the relative price of R\&D labor and materials, separate PPPs for other R\&D cost categories are less essential, and a simpler version using GDP PPPs for these other categories should suffice. Our preferred PPPs are used to compare international $R \& D$ costs and intensity. The results suggest that the efforts devoted to R\&D in each country are more similar across countries than is apparent using the nominal R\&D intensities that are currently the norm.

Sean M. Dougherty

OECD Economics Department

2, rue Andre Pascal

75775 Paris Cedex 16

France

sean.dougherty@oecd.org

Robert Inklaar

University of Groningen

Faculty of Economics

PO Box 800

9700 AV Groningen

The Netherlands

R.C.Inklaar@rug.nl
Robert H. McGuckin †

The Conference Board

845 Third Avenue

New York, NY 10022

Bart van Ark

University of Groningen

Faculty of Economics

PO Box 800

9700 AV Groningen

The Netherlands

h.h.van.ark@rug.nl 


\section{Introduction}

Concerns with science and technology (S\&T) capabilities are widespread in the United States as well as in other developed countries. This is understandable in light of the importance of knowledge and technology in generating long-run growth of productivity, per capita income and employment. Trends and levels of R\&D spending and, in particular, ratios of R\&D expenditure to GDP or national income are often used as a measure of innovativeness since they capture the resources devoted to achieving future technological change. ${ }^{1}$ In Europe, for example, governments at the Barcelona European Council noted that European R\&D expenditures are well below those of the United States and set a target to dramatically increase R\&D spending from $1.9 \%$ of GDP to $3.0 \%$ by 2010 (European Commission, 2002).

Whereas nominal R\&D intensity provides a measure of the burden (in monetary terms) on society of $R \& D$ activities, it is less informative about the real resources devoted to $R \& D$ because it does not take into account differences in relative prices of R\&D inputs across countries. For this purpose, R\&D-specific purchasing power parities (PPPs) are needed, which measure how much needs to be spent in a country to acquire one U.S. dollar's worth of R\&D inputs. ${ }^{2}$ Hence R\&D expenditures which are converted at R\&D PPPs will give a better measure of the differences in actual resources devoted to R\&D between countries. In this sense, PPPs are comparable to price deflators that adjust nominal values for price changes to arrive at real, or volume, measures.

When making international comparisons of R\&D, PPPs should reflect differences in relative prices. Since R\&D output prices cannot be directly measured, we need to focus on the prices of R\&D inputs. Most studies and statistics use aggregate proxies such as the PPP for GDP but these will generally not suffice. While GDP PPPs reflect relative prices of primary inputs -

\footnotetext{
${ }^{1}$ Policy discussions must also consider the productivity and composition of these efforts, which are likely to differ across countries (and industries), as well as the magnitudes of the spillovers generated. In examining these issues, it is important to develop R\&D capital stock measures rather than focus only on current expenditures. While these issues are not dealt with in this paper, PPPs and price deflators are basic building blocks for this type of analysis. ${ }^{2}$ As rates of equivalence for comparable goods in local currency prices, purchasing power parities (PPPs) have the same units as exchange rates. If PPPs and exchange rates are the same, then there is no difference in relative prices or cost across countries. However, there are many reasons why exchange rates are not good substitutes for PPPs. Of particular relevance to $\mathrm{R} \& \mathrm{D}$, there is no necessary reason why the relative prices of goods that are not traded internationally should conform to exchange rate values. Exchange rates are also vulnerable to a number of distortions, e.g., currency speculation, political events such as wars and boycotts, and official currency interventions, that have little or nothing to do with the differences in relative R\&D prices across economies (NSF, 2002).
} 
labor and capital - each input's representation in GDP does not reflect its importance to R\&D, and they are not specific to R\&D. Moreover, GDP is based on the concept of final goods and services, rather than the intermediate goods and services that make up a large part of $R \& D$ expenditure. Finally, use of GDP PPPs does not capture differences in the industrial composition of R\&D across countries. While use of industry-level nominal R\&D expenditure can partially address the composition issue, remaining distortions in prices can be a serious problem.

Taking the latter point a step further, when focusing on real R\&D intensities by industry, not only the numerator - R\&D expenditure - needs to be converted using a specific R\&D PPP, but the denominator - industry output - requires an industry-specific output PPP. The use of a GDP PPP to adjust for relative price levels in manufacturing would be equally inappropriate. Recent experience with industry-level PPPs from the International Comparisons of Output and Productivity (ICOP) project suggests that substantial differences exist between manufacturing output PPPs and GDP PPPs, even for economies at similar levels of development (van Ark, 1993; van Ark and Timmer, 2001). Therefore PPP adjustments - taking account of differences in the structure of relative prices of $\mathrm{R} \& \mathrm{D}$ inputs and output across economies and industries - may be worth the considerable effort required for their measurement. ${ }^{3}$

A search of the literature finds relatively little empirical work on R\&D price indexes, particularly across countries. In fact, the latest R\&D PPP estimates we could find were done in the early 1990s for the year 1985. Typically, the issue is either ignored because detailed price data are not available or a GDP PPP is used in cost comparisons. For comparisons of R\&D intensity, nominal values are usually employed. To compare R\&D expenditure over time, a GDP deflator is most commonly used. The lack of good measures in the area of R\&D price indexes has not gone unrecognized. Zvi Griliches lamented the lack of good information on the "price" of R\&D in his remarks 20 years ago, on the occasion of the NBER Conference on R\&D, Patents, and Productivity (Griliches, 1984). Griliches further emphasized the importance of having reliable information on $\mathrm{R} \& \mathrm{D}$ and its price to compare expenditures and intensities in his Presidential Address to the American Economic Association (Griliches, 1994).

\footnotetext{
${ }^{3}$ The Frascati Manual (OECD, 1994: 12) states that "[R\&D intensity] indicators are fairly accurate but can be biased if there are major differences in the economic structure of the countries being compared." Arguably since R\&D is not a tradable commodity and one of its major components is labor, whose price exhibits great differences across countries, such differences are probable.
} 
This paper brings together a wide range of statistical data to develop relative R\&D prices for 19 manufacturing industries in six OECD countries - France, Germany, Japan, the Netherlands, the United Kingdom and the United States - with the U.S. as the base country. This exercise is undertaken for two benchmark years, 1997 and 1987, chosen because these are years with information from the U.S. Economic Census, benchmark international PPP studies on industry output, and comprehensive R\&D surveys from each of the countries. Industrial census data and collections of international prices are used to compare prices of intermediate goods. Data from national R\&D surveys of business enterprises are used to develop R\&D-specific prices and quantities. Interpretation of the data was also guided by information collected in over 35 interviews of $R \& D$ executives at international affiliates of multinational companies in four of the most R\&D-intensive industries, pharmaceuticals, computers, telecommunications equipment, and motor vehicles. The interviews were invaluable in understanding issues of comparability in different countries' data, due to differences in reporting practices, tax regulations, and interpretations of R\&D definitions, among other issues. Moreover, we gleaned important qualitative information that was useful in interpreting the implications of the results. ${ }^{4}$

In the sections that follow, we first review previous research on R\&D PPPs and its limitations. Next we describe our estimates of manufacturing R\&D PPPs for 1997 and 1987. These PPPs are used to compare international R\&D cost levels and intensity. We then assess differences with current practices. We find that our preferred R\&D PPP measure can be simplified without a large impact on the results. This alternative resembles the Griliches-Jaffe R\&D deflator and is far easier to construct than our most preferred measure. Both measures differ substantially from the GDP PPP.

\section{Previous research on $R \& D$ PPPs}

This study is not the first to address the problem of estimating PPPs for R\&D. Nevertheless there has been relatively little effort to create R\&D PPPs, particularly compared to the volume of work carried out by official statistical agencies in the price index area. While there

\footnotetext{
${ }^{4}$ The interviews are not described in detail in this paper. More information can be found in McGuckin et al., 2004a and 2004b. Large multinational R\&D performers in four high-tech industries, in the United States, Japan, and Europe, were selected for face-to-face interviews. Even with the small sample, coverage of many countries' industries is substantial. Interviews involved structured discussions about firms' R\&D organization, composition, and reporting practices. A detailed financial questionnaire on R\&D costs items and expenditures was also completed by about one-third of the interviewed firms.
} 
are many reasons for this state of affairs, an important factor is that $R \& D$ expenditures are not yet incorporated into the System of National Accounts. ${ }^{5}$

A key issue in estimating R\&D PPPs is that the output of R\&D cannot be easily defined. If $R \& D$ were a typical economic activity, like the production of steel or cotton, then standard measurement of quantities and prices could be applied. However, the results of R\&D often are ideas and other intangibles which are typically in the "hard-to-measure" area. ${ }^{6}$ Moreover, R\&D services are often transferred within the firm rather than traded on markets so prices are hard to measure. As a result, measurement of $R \& D$ prices has generally focused on constructing input price indices, which can be used to assess differences in costs. This approach has characterized all the major studies from the 1960 s onwards. ${ }^{7}$ Given the difficulties in measuring output even for relatively well-defined high-technology products, such as Information Technology (IT) capital, some caution should be used when interpreting price indices for R\&D.

\subsection{Overview of earlier studies}

In most of the literature, the relative cost of R\&D across countries is estimated based on prices for a basket of "standard" R\&D inputs at the economy-wide level. ${ }^{8}$ Freeman and Young (1965) performed the first of these studies. Their work was undertaken for the year 1962, before the first edition of the Frascati Manual (OECD, 1963) and they did not benefit from the more comparable survey instruments in use today. Nevertheless they use expenditure categories similar to those we apply in this study. Freeman and Young estimate a PPP for R\&D by breaking up total R\&D expenditure into labor costs, materials, other current and capital expenditures. For labor costs they calculate the wage cost per worker in $\mathrm{R} \& \mathrm{D}$ and assume this is also appropriate for other current expenditure. For materials and capital expenditures they assume the exchange rate is the appropriate price.

\footnotetext{
${ }^{5}$ See Fraumeni and Okubo (2005) for recent work on developing R\&D measures in the framework of the U.S. National Income and Product Accounts.

${ }^{6}$ In related work, we have found that although research is for the most part intangible, development is quite different and has physical dimensions that should be relatively easier to measure (McGuckin et al., 2004b).

${ }^{7}$ One quite different approach has been applied to pharmaceuticals, where the total cost of an innovation is priced out over its development cycle, including the cost of failures (DiMasi et al., 2003). While this approach has great appeal when assessing the cost of a specific innovation like a drug, it is harder to apply in other industries, and says little about the relative cost of performing R\&D in different countries.

${ }^{8}$ The Conference Board (1976) and Mansfield (1988) directly queried firms about the relative cost of selected R\&D inputs, but this approach is difficult to generalize to multiple industries and countries.
} 
Brunner (1967) compares the cost of research projects subcontracted by the U.S. Department of Defense across a number of European countries. For these projects, subcontractors supply budget sheets, which contain data on total costs, including wages, benefits, support and overhead costs. The cross-country comparability issues are likely to be smaller than in the Freeman and Young study, since the Department of Defense imposes similar budget standards on all subcontractors. However, the estimate includes a very specific subset of R\&D and it is unclear if the budgets include all R\&D costs (e.g., capital expenditures).

The work by MacDonald (1973) extends the previous two studies to sixteen OECD countries by calculating R\&D PPPs relative to the United Kingdom. ${ }^{9}$ He distinguishes between labor cost, other current cost and capital expenditure. For the countries included in the Brunner (1967) study, MacDonald uses wage data for scientists and for technicians based on that study. For the other countries he relies on average wage costs (total labor cost over total number of R\&D workers). His estimate of a capital PPP is based on relative prices from trade statistics, weighted using the aggregate expenditure on these products. For other current expenditure, he assumes the exchange rate is applicable. Based on these figures, he finds that R\&D in the United States is around $40 \%$ more expensive and Japan $70 \%$ cheaper than in the United Kingdom (see Table 1).

\section{[Table 1 about here]}

In 1979 the OECD published a study, presenting calculations for R\&D deflators for the 1966 to 1976 period and an R\&D PPP for 1970 (OECD, 1979). Four cost categories are distinguished in the study: labor, other current costs, land and buildings and instruments and equipment. The labor PPP is calculated as the average labor cost per R\&D worker. A PPP for other current expenditure is proxied as the relative price of current government expenditure other than salaries, from International Comparisons Project (ICP) studies. The two capital categories are also ICP-based: for land and buildings the PPP for non-residential/commercial buildings is used, while for instruments and equipment, the PPP for electrical machinery items is used.

\footnotetext{
${ }^{9}$ In Table 1, we convert these to cost levels relative to the United States to facilitate comparability. This is appropriate since all PPPs are aggregated from individual cost category PPPs using U.K. weights, in effect creating a Laspeyres-type index. Although the Laspeyres index has its weaknesses, it is transitive.
} 
The most recent study is by Kiba, Sakuma and Kikuchi (1994). The countries they cover are France, Germany, Japan and South Korea, with the United States as the base country. Their breakdown of cost categories is more refined than in previous studies: they distinguish materials spending from other current expenditure and they break down capital expenditure into machinery \& equipment, land \& building and other assets. Since such a detailed breakdown was not available for all countries, estimates were made using data from countries where these distinctions could be made.

Kiba et al.'s (1994) basic approach is to select price parities from GDP final expenditures (ICP studies) to proxy each of the R\&D input cost categories. They select their price parities based on the composition of items in the R\&D industry of Japan's input-output use table. In cases where they cannot identify relevant input price parity headings from ICP, they use the exchange rate as the relative price. This same selection of prices is used for all countries. Their match between R\&D categories and price parities is very rough and is based on only the Japanese structure of R\&D inputs.

If the input-output tables were sufficiently comparable across countries, use of the input structure for the R\&D industry could be very useful. However, our research indicates that the data for the R\&D industry are not comparable. The problem is that the inputs allocated to the R\&D industry depend on the institutional structure of the country and the related issue of which facilities are designated as R\&D labs by data collectors. German R\&D firms, for example, obtain a significant share of their intermediate inputs from the education sector, while in other countries, this share is non-existent. In the United States only stand alone-laboratories are included in the R\&D industry and their inputs are very different from integrated facilities (McGuckin et al., 2004b).

\subsection{Drawing lessons}

The methodologies used in these studies for calculating R\&D PPPs contain several common features. As OECD (1979) notes, an ideal approach would be to calculate the labor cost per employment occupational category (scientist, technician or support), but limitations on the disaggregation of labor expenditure prevents this method from being implemented broadly. While Kiba et al. (1994) use ICP government and educational labor PPPs as a proxy for an R\&D labor PPP, this is likely to be a less appropriate measure of the average labor cost per R\&D 
worker. The latter method is commonly employed in studies on an economy-wide basis; we adopt the same approach at the industry level for this study.

Calculating a PPP for the other current expenditure category is a problem because it is difficult to determine exactly what inputs are in this category. In general, there are two major groups, purchased goods and purchased services. The first would include material costs (raw, non-durable goods) but, depending on statutory tax depreciation provisions, also machinery and instruments. The second, frequently referred to as overhead costs, can include anything from building rent to the purchase of scientific journals.

The procedure used by MacDonald (1973) that assigns the market exchange rate for materials and the labor PPP for overhead is probably too crude. Overhead, for example, includes much more than simply extra labor cost. OECD (1979) and Kiba et al. (1994) take a more promising approach by using product-specific ICP expenditure PPPs to come up with a PPP for this cost category. A further point to note is that the price consumers pay for final consumption goods or firms for investment goods may not be relevant for intermediate input purchases by R\&D labs.

MacDonald (1973), OECD (1979) and Kiba et al. (1994) develop capital PPPs using import and export prices. Unfortunately, these prices may not reflect prices paid for similar goods by R\&D laboratories. It is probably more appropriate to select one or more PPPs for both land and buildings and instrument and equipment, as is done by the OECD (1979) and Kiba et al. (1994) using ICP expenditure PPPs.

Finally, the aggregation used in most of these studies could be improved. The earlier studies use a weighted average of the category PPPs to calculate their economy-wide R\&D PPPs. While the MacDonald, OECD, and Kiba et al. studies use a Laspeyres-type aggregation, for many countries they do not have complete expenditure weights. None of the studies calculates a Fisher-type index or some multilateral index, which are the preferred methods in PPP studies (Kravis, Heston and Summers, 1982; van Ark and Timmer, 2001).

Despite the various shortcomings of each study, the studies provide a similar bottom line. Table 1 shows that the relative price of $R \& D$ of other countries compared to the United States had a strong upward trend between 1962 and $1985 .^{10}$ The table focuses on those countries that

\footnotetext{
${ }^{10}$ Some studies originally used a different base country, but all have been recast to use the United States as the base country to facilitate the comparison.
} 
are included in this study. While R\&D was initially less expensive outside the U.S. in every country, the gap narrowed substantially in the 20 years covered by these studies. For example, between 1962 and 1985 the relative cost level of R\&D in Germany rose from around 60 percent of the U.S. in the early 1960 s to 85 percent in 1985 . These increases partly reflect the large changes in the exchange rates over these years, but changes in real cost play a role as well.

\section{R\&D PPP Estimation in Manufacturing}

This work is motivated by concerns about the appropriateness of the current practice of using GDP PPPs for R\&D expenditure and international R\&D intensity comparisons based on nominal expenditures and output. Limitations on the availability and comparability of international data are the biggest obstacle to more systematic development of R\&D-specific PPPs. While not all problems associated with calculating R\&D PPPs can be resolved, there have been a number of improvements in data in recent years and there are a number of areas for potential improvements. For example, work coordinated by the University of Groningen's ICOP group has created databases of industry-level PPPs, supplementing the more widely available expenditure PPPs from the ICP programs of the United Nations, World Bank, OECD and Eurostat (see Kravis et al., 1982; van Ark, 1993; and van Ark and Timmer, 2001).

In addition, the comparability of R\&D data has improved, in part through the efforts of national statistical agencies guided by the OECD's Frascati Manual (OECD, 1963-2002). Nonetheless, it is far from clear whether companies in different countries report R\&D costs in a similar way. For example, in one country companies may include purchases of new computers under current expenditure while in others it may be reported as a capital expenditure. ${ }^{11}$ This is one reason for the use of the firm interviews in our work. Still, the problems with comparability should not be overdrawn. The studies surveyed in Table 1 demonstrate that similar results are found despite large differences in data availability and methodology.

\subsection{Methodology and procedures}

We develop estimates of industry-specific R\&D PPPs by aggregating individual price parities for major categories of R\&D expenditures with expenditure share weights derived from national surveys. On this basis we obtain R\&D PPPs for 19 manufacturing industries which are

\footnotetext{
${ }^{11}$ See McGuckin et al. (2004b) for more discussion of comparability problems.
} 
then aggregated to the total manufacturing level. The principal results of these calculations are two measures that we later use in assessing the cross-country differences. The first is an R\&D PPP which measures the price of an R\&D unit in a particular country relative to the price in the United States, the base country. This measure is in units of local currency per U.S. dollar and can be used to "deflate" R\&D expenditures in the spatial dimension. Second, by dividing the R\&D PPP by the dollar exchange rate, we obtain the relative cost (price level) of an R\&D unit of input compared with the base country.

The R\&D PPP for each individual industry is estimated from an aggregation of relative R\&D input prices (price parities or just PPPs) using corresponding R\&D expenditure shares as weights. For each industry and country pair, cost weights of the base country $u$ - the United States - are used to create a Laspeyres PPP,

$$
P P P_{L}^{x, u}=\sum_{i} w_{i}^{u} P P P_{i}
$$

Equation (1) is simply a share-weighted average of the individual PPPs for four input categories, labor, materials, other current costs, and capital expenditure, indexed by $i$. Weights are based on the share of each category's expenditure in R\&D (of the base country in U.S. dollars):

$$
w_{i}^{u}=C_{i}^{u} / \sum_{i} C_{i}^{u}
$$

where $i$ and $j$ index the cost categories. For the comparison country $x$, we use that country's expenditure weights to calculate a Paasche PPP,

$$
\begin{aligned}
& P P P_{P}^{x, u}=\sum_{i} w_{i}^{x} P P P_{i} \\
& w_{i}^{x}=\left(C_{i}^{x} / P P P_{i}\right) / \sum_{i}\left(C_{i}^{x} / P P P_{i}\right)
\end{aligned}
$$

where $w_{i}^{x}$ is the expenditure share of input category $i$ in the comparison country $(x)$ converted into U.S. dollars using the corresponding PPP. Taking a geometric average of (1) and (3) yields a Fisher PPP, the measure of the price of R\&D in local currency units of country $x$ per U.S. dollar. 
Dividing these PPPs by the exchange rate provides a unit-free index measure of relative R\&D costs compared to the United States, which is the base country in all the calculations. Thus, all of the comparisons are made on a bilateral basis. ${ }^{12}$ We now turn to the details of the PPP calculations and their sensitivity to various assumptions and data. ${ }^{13}$

\subsection{R\&D input prices and weights}

Computation of R\&D PPPs requires both prices and weights for each category of R\&D input. We identify four main categories of R\&D input: labor, materials, other current costs (“overhead"), and capital. Weights for each category are based on each input's representation in R\&D expenditure. This industry-level expenditure information comes from summary data compiled by the OECD based on national R\&D surveys in each country. We also use industryspecific R\&D input prices for labor and materials and economy-wide prices for other current costs and capital. The labor PPPs rely most heavily on comparions of wages for R\&D personnel, derived primarily from the national R\&D surveys. We develop independent estimates for the price of material inputs, other current expenditures, and capital using the industry-of-origin PPPs from the University of Groningen's ICOP program, which are based on item-level matches derived from production census and industrial survey data in the United States, European Union, and Japan. We supplement this information with PPPs derived from ICP studies using the expenditure approach (OECD, 2002) after making appropriate adjustments to "peel-off" estimated margins for transportation and distribution (see Jorgenson and Kuroda, 1992; van Ark and Timmer, 2001). The firm interviews, as described in McGuckin et al. (2004a), are used to inform the necessary assumptions that are made regarding the structure of R\&D expenditure and about how to use the data in a way that approaches a constant-quality of input basis.

\section{[Table 2 about here]}

\footnotetext{
12 These bilateral PPPs for each country pair differ from multilateral PPPs as used in the expenditure PPP programs of ICP (see, for example, Kravis, Heston and Summers, 1982). In practice this could mean that some of our pairwise R\&D PPP estimates are not transitive. However, given that we only cover six countries in this study with relatively similar cost shares, the gains from using multilateral indices were found to be modest.

${ }^{13}$ Note that the industry-level PPPs are aggregated across industries using a Fisher index, in order to obtain manufacturing-wide PPPs. This procedure takes account of differences across countries in industry weights.
} 
Table 2 provides an overview of measures and sources used for the R\&D input prices for the construction of the R\&D PPP measure. Below we discuss our input price measures and weights in some detail and examine possible variants to our preferred measure. Additional details on the estimates are available in an on-line Appendix (McGuckin et al., 2004a).

\section{Labor}

Labor is the largest component of $R \& D$ cost, averaging about half of total expenditures. Average R\&D compensation per R\&D employee, based on national R\&D survey information, measures the price of $R \& D$ labor for $R \& D$ performed within business enterprises (intramural). For each country and industry, we calculate the average wage of R\&D labor by dividing $R \& D$ labor expenditures by the corresponding number of full-time equivalent R\&D personnel. These wages are then divided by the wage of the base country, yielding the relative price (PPP) for $\mathrm{R} \& \mathrm{D}$ labor.

This procedure implicitly assumes R\&D personnel in different countries are equally productive, ascribing any differences in wages to higher labor cost, not to higher productivity. Data limitations prevent us from grouping employees by function or qualification and comparing their relative wages across countries before they are aggregated to form R\&D labor PPPs. However, in the interviews, firm officials stated that the biggest differences in compensation are across technical fields and these variations are likely to be captured by average compensation in each industry. Firm officials also indicated that the skills of R\&D personnel in routine development work, which constitutes the bulk of $R \& D$, are quite similar across countries. This suggests that the tacit assumption that workers in each country have comparable qualities or capabilities may not be that far from the reality. ${ }^{14}$ However, while this assumption may be realistic for the group of (advanced) countries we study here, much more caution would be necessary if countries like Mexico or China were included in a comparison.

A major hurdle in developing R\&D compensation rates is the coverage of the U.S. R\&D survey, which only collects data on the number of research scientists and engineers (RSEs) in its survey of business enterprises. In contrast to all other countries there is no information on the

\footnotetext{
${ }^{14}$ This assumption is also supported by an insignificant correlation of labor price with the support share of R\&D personnel at the industry level. The support share of R\&D personnel provides a proxy for (basic) scientific and engineering skills, and is the only comparable skill measure available outside the United States.
} 
number of support staff employed. ${ }^{15}$ In order to determine the number of support personnel in the United States, we examined a wide range of alternative data sources. A careful assessment of this evidence suggests that the support share in an industry's total employment is a fair representation of its support share in R\&D. More detail on this evidence, which was supported by the firm interviews, is described in McGuckin et al. (2004a). In addition, our independent estimate of the U.S. share is in the range of that found for the other countries in this study.

Because only R\&D personnel headcount is collected rather than full-time equivalents in Japan, the Japanese R\&D labor price is probably understated. If part-time R\&D personnel are counted as full-time, then compensation per employee is underestimated. While this distinction may not be important in practice, one study made a large downward adjustment to the personnel count (NSF, 1998). On the other hand, given Japan's typically higher working hours, the net effect of the part-time/full-time difference on average compensation may not be large.

\section{Other Inputs}

Materials and supplies represent about $20 \%$ of R\&D expenditure. The interviews suggest that the majority of expenditure in this category consists of prototypes of new products, or in other words, the products of the industry itself. Therefore, we use own-industry output PPPs, adjusted for margins so that they represent the purchase prices of own-industry goods used as inputs. ${ }^{16}$ These prices come from industry-of-origin studies of item-level matches of industrial census data for specific industries in each country, and are described further in Section 4.

It was more difficult to identify prices for other current costs and these are important at $24 \%$ of R\&D expenditure. According to the firms we interviewed, this category includes an array of goods and services typically described as "overhead." Detailed financial data for about 10 firms showed that this category includes such items as communications services, rent, utilities, and non-capital computers and instruments. We were able to identify industry-of-origin (ICOP) and final expenditure (ICP) price parities that matched many of these goods and services. ${ }^{17}$

\footnotetext{
${ }^{15}$ Information on the number of technicians is also not (explicitly) collected in the United States. However, we have found that most firms appear to make little distinction between RSEs and technicians, and tend to include them in reported RSEs.

${ }^{16}$ Since output PPPs do not reflect transportation and distribution margins, we add these margins back in using information from input-output tables, in order to treat these goods as purchased inputs to the industry.

${ }^{17}$ For ICOP (intermediate) prices, this means that transportation and distribution margins are added back in, and for ICP (final expenditure) prices, tax margins are removed ("peeled off"). These margins are estimated using input/output tables.
} 
However, this information is not industry-specific, so we implicitly assume that the relative prices of these overhead goods and services are similar across industries. While most goods purchased for use in $R \& D$ programs are obtained in national markets, they may not be used in the same proportions in all industries. Since we do not have any information about the expenditure shares within this category, we use an unweighted average of 11 price "headings."

For high-tech inputs such as computers, it is particularly difficult for the PPPs to take full account of quality differences. Since there is a wide spread in the prices of these inputs, the resulting price parity for this category is somewhat sensitive to what prices are included and excluded, especially in the case of Germany and Japan. Yet some simple experiments in which we removed outlying prices suggest that the impact on the aggregate R\&D PPP is not that large (see McGuckin et al., 2004a).

It was also difficult to develop prices for capital expenditures; they are, however, the smallest category of R\&D expenditure, at $9 \% .{ }^{18}$ We followed a similar approach to that used for other current costs, and selected five ICOP and ICP price parities that correspond to plant and equipment headings appropriate for capital expenditures. Again, since we do not have an industry-level breakdown of capital expenditure, we implicitly assume that the proportions of capital inputs and relative prices of capital inputs used in each industry are similar across countries.

The assumption of common patterns and national markets seems more plausible for the other current and capital costs than for labor or materials. But the lack of systematic weights and potential quality adjustment problems for the prices of current cost and capital items means that we are less confident about the PPPs for these inputs. Therefore, we explore some alternative R\&D PPPs that use different proxies for these input categories. The most interesting of these uses the industry-specific material PPPs for all of the non-labor inputs, while another uses the GDP PPP. These are described further in Section 3.5.

\footnotetext{
${ }^{18}$ In considering capital inputs, a number of additional difficulties arise. Some countries appeared to have quite low capital expenditures. This could be related to a greater tendency to own land, in which case the opportunity costs of owning are not accounted for (some interviews suggested this). To the extent that firms in other countries are more likely to lease land, capital expenditures could be misleading. Moreover, capital service flows based on appropriately valued capital stocks are the appropriate concept, but given data limitations we can only consider current capital expenditure. Still, capital expenditures were rarely a large share of expenditure on R\&D, so the results may not be substantially affected by these problems.
} 


\section{Weights (shares)}

Weights for each of the four categories of inputs by country are shown in Table 3. Each of these expenditure shares for total manufacturing is built up from expenditures of 19 manufacturing industries in the national R\&D surveys. As shown in the table, the expenditure shares from national statistics are in a similar range as those we obtained from firm interviews. In fact, if we compare the 10 firms' financial information we obtained in interviews with corresponding industry expenditures shares in firms' home countries, their labor shares only differ by about $2 \%$ on average.

\section{[Table 3 about here]}

There were two categories of expenditure where we had to make assumptions about the shares. First, expenditure information on materials and supplies is not collected in France, Germany and the Netherlands. For these countries we assigned the average of the United States, United Kingdom, and Japan's shares of non-labor, non-capital expenditure. Second, the U.S. R\&D survey only collects R\&D depreciation, so it is not comparable with the other five countries' $\mathrm{R} \& \mathrm{D}$ capital expenditures. Moreover, because accounting requirements for $\mathrm{R} \& \mathrm{D}$ (at least in the United States) restrict the capitalization of $R \& D$-specific assets, depreciation is likely to be quite different from even the average expenditure on capital. In fact, the U.S. depreciation share is far lower than the other countries' capital expenditure shares, at only $1.3 \%$, compared to the $9 \%$ average for the other countries. The $9 \%$ figure is also closer to the typical capital expenditures of the firms we interviewed. We therefore use the industry-specific average of the other five countries' capital expenditure shares as an estimate of the U.S. share. More details about the interviews and the basis for our assumptions about the R\&D input prices and weights are described in McGuckin et al. (2004a).

\subsection{Discussion of the Results}

Table 4 provides estimates of the R\&D PPP and the price level or cost of R\&D for each country. These price levels represent the relative cost of a unit of $R \& D$ input in each country compared with the United States. $R \& D$ price levels are defined as the R\&D purchasing power parity (PPP) divided by the exchange rate of the country's currency relative to the U.S. dollar. 
These levels represent costs relative to the United States. If the PPP is the same as the exchange rate, the price level equals 100 .

\section{[Table 4 about here]}

Based on these results for 1997, manufacturing R\&D in Germany and Japan is 10\% to 15\% more expensive than in the United States, while in France, Netherlands, and the United Kingdom, $\mathrm{R} \& \mathrm{D}$ is $5 \%$ to $15 \%$ less expensive. Because the expenditure weights are relatively similar across countries, these cost differentials are driven by the differences in the relative prices of input categories. Comparative price levels for each R\&D input category are shown in Table 5 for total manufacturing. Lower prices in France, Netherlands, and the United Kingdom can be traced to lower R\&D labor prices. The higher prices in Germany and Japan are attributable to the high price of other current costs, or "overhead" expenses. For both countries, wholesale and retail trade, and transportation and storage have the highest relative prices (McGuckin et al., 2004a). In Japan, insurance is also relatively expensive, while in Germany, electricity, gas and water are relatively costly.

\section{[Table 5 about here]}

The approximate magnitude of the price differences that we observe using these newly constructed R\&D PPPs are similar in character to those reported in the interviews. In most cases, the cost of performing routine $R \& D$ was described as not varying all that much across the countries included in this study. The differences we measure for total manufacturing in the 5$15 \%$ range are consistent with these observations.

\section{Labor prices and inter-industry variation}

Since labor represents the largest share of $R \& D$ and the data are R\&D- and industryspecific, it is worth examining the labor PPPs more closely. Interviews suggest that R\&D labor

compensation can vary widely between technical fields and that the mix of technical fields varies greatly from firm to firm and industry to industry. Labor costs do vary considerably across industries, and particularly across countries, even within industries. 
Due to shortage of space, this paper does not show the results for the individual 19 manufacturing industries. ${ }^{19}$ Inter-industry variation is illustrated by the coefficients of variation (CV) for price levels of R\&D labor relative to the United States. These are especially wide for the Netherlands and United Kingdom, where the CVs are 0.38 and 0.40 , respectively. ${ }^{20}$ In contrast, France has the narrowest range of relative labor price levels across industries, with a $\mathrm{CV}$ of 0.16. An important question is whether the differences across industries are larger or smaller than the differences across countries. We performed a two-way ANOVA and found significant differences across both industries and countries, with more of the variation coming from across countries, than from across industries. One explanation for the importance of the country effect is national policies and union negotiations in most of the European countries. The large differences in R\&D labor prices across both countries and industries illustrate the importance of including R\&D labor explicitly in R\&D PPPs.

\section{Non-labor input prices}

The three remaining categories of input prices used for the construction of the R\&D PPPs are materials, other current costs, and capital expenditures. Only the materials prices are industry-specific. The variation in relative price levels across industries for materials is nearly as large as that for labor. The coefficient of variation across industries for each of the five comparison countries is between 0.20 and 0.42 . As with labor, an ANOVA analysis shows that the differences across both industries and countries are statistically significant.

$R \& D$ PPPs for 1987

Using the same methods and data sources, we also derive relative prices in 1987 for the same four categories of R\&D inputs and aggregate them using R\&D expenditure weights. Although for some countries the source material is less extensive and detailed (in particular for the Netherlands), we are able to follow very similar procedures. The results of this exercise at the level of total manufacturing are shown by country in Table 6.

\section{[Table 6 about here]}

\footnotetext{
${ }^{19}$ See Table B6 in McGuckin et al. (2004a).

${ }^{20}$ Coefficients of variation are calculated as the standard deviation divided by the unweighted arithmetic mean of the relative price levels of R\&D labor by industry.
} 


\section{[Table 7 about here]}

Comparing the relative $R \& D$ price levels for 1987, we observe that the United Kingdom is least expensive, 22\% cheaper than the United States, and France, Germany, and the Netherlands are most expensive, at 5\% to 15\% more costly than the U.S.; Japan is nearly tied with the U.S. The lower R\&D prices in the U.K. are driven most importantly by lower R\&D labor prices, while higher prices in France, Germany, and the Netherlands can be linked to the high price of capital. The relative price levels for the input categories are shown in Table 7.

\subsection{Sensitivity of the R\&D PPP; alternative measures}

An important question for the interpretation of our results is how sensitive the R\&D PPPs are to the assumptions we make. In general, our R\&D PPPs will be more accurate if the underlying relative prices are well-measured, if they refer specifically to $R \& D$ in each industry and if there are industry-specific weights to combine them into a single index. Of the four R\&D input categories, we are most confident in our measure of the price of R\&D labor, since it is collected specifically for R\&D within each industry and country, and is nearly comprehensive across countries. ${ }^{21}$ As mentioned before though, a drawback is the lack of a breakdown by labor type. The materials inputs are next best, since they are industry-specific and the coverage in each industry is high, although they are not R\&D-specific.

As discussed in Section 3.2, the prices for other current costs and capital costs in the preferred R\&D PPP construction are more problematic. Here we have a limited number of individual item prices, some of which could be improved with hedonic quality adjustments, and no weights for the prices that make up the input categories. Although the choices of price proxies were informed by interviews of R\&D-intensive firms, we are less confident about these prices because they are not quality-adjusted, there are no weights, and the available price data is relatively sparse.

In many respects the choices we face are simply echoes of the earlier studies. But here we develop several alternative versions of the R\&D PPP, and use them to ascertain the sensitivity of

\footnotetext{
${ }^{21}$ This discussion abstracts from various issues associated with the R\&D survey design. In particular, the collection of expenditure data at the firm level coupled with the classification of a firm into a single industry means that for diversified firms the industry numbers involve a mix of industries.
} 
the resulting R\&D PPP. The specific input prices used in developing these alternative R\&D PPP estimates are described in Table $8 .^{22}$

\section{[Table 8 about here]}

In addition to our "preferred" R\&D PPP discussed above, labeled (a), we estimate two other versions, labeled (b) and (c), in addition to the current practice labeled (d). The alternatives discussed here use the same industry-specific measure of the price of R\&D labor. They also use the same weights for the individual inputs. Only the prices used for the input categories are varied. We compare these different versions of the R\&D PPP to understand the sensitivity of the results to the selection of price proxies for the input categories.

Both alternative R\&D PPPs are roughly based on the concept of the Griliches-Jaffe R\&D deflator, which combines the price of labor with a broader measure of economy-wide price changes (Jaffe, 1972; Griliches, 1984). ${ }^{23}$ Alternative (b) uses industry-specific PPPs for materials and supplies to reflect the cost of prototypes and associated goods. For other current costs and capital expenditure it borrows from the current practice of using the GDP PPP. This approach makes the assumption that the relative price levels of other current and capital R\&D costs equal the average relative price level for the aggregate economy. This alternative is referred to as "lab+mat+GDP" and since it is strongly industry-specific, we consider it to be the most conceptually appropriate alternative to our preferred measure.

Alternative (c) uses the GDP PPP to proxy the price of all non-labor inputs, including materials and supplies. This alternative is referred to as "lab+GDP," and it combines industryspecific R\&D labor with economy-wide GDP final goods prices. Finally, we compare the results with the current practice alternative (d), which uses the GDP PPP for all R\&D inputs and is widely used by statistical agencies and national science authorities for international comparisons of science and technology indicators. As argued above, use of GDP is particularly problematic

\footnotetext{
${ }^{22}$ We estimated several other variants as well, making a variety of different assumptions about the prices used for other current and capital costs. The result of these variants was in each case similar to either alternative (b) or (c), so they are not shown here.

${ }^{23}$ The Griliches-Jaffe deflator originally referred to a proxy R\&D price index for the United States that combined the hourly compensation index with a $51 \%$ weight and the implicit deflator for non-financial corporations with a $49 \%$ weight (Griliches, 1984). We analogize this interpretation to spatial comparisons by using PPPs instead of deflators, and extend it to use industry-specific R\&D labor prices and weights from actual R\&D expenditure shares.
} 
since it includes a wide range of products and services not used in $R \& D$, and the concept is based on final expenditure.

The use of these alternatives obviously does not cover the entire range of possible measurement problems. Although we do not have systematic quantitative estimates of potential error, we examine here several simple changes in assumptions within each of the alternative estimates to see if they produce major changes in the resulting R\&D PPP. For instance, we have excluded some outliers from the set of prices we use for other current costs in calculating our preferred R\&D PPP for Germany and Japan. This results in a drop in the input prices in the range of 6-13\% relative to the United States. But in such instances the resulting R\&D PPPs are only affected by $1.0-3.5 \%$. This result is typical of the tests we have conducted.

When we use the Fisher PPP aggregation formula described above in section 3.1 to aggregate prices across countries, large differences in the underlying weights in fact imply a wide range of possible outcomes. This range is referred to as the Paasche-Laspeyres spread, and is usually large when countries have very different price structures. Since the six countries in this comparison are at a similar level of development, we did not expect that this should be a significant problem, and it is not. The Paasche-Laspeyres spread is on the order of $2-3 \%$ for most comparisons, suggesting that differences in the weights are not large enough to meaningfully affect the comparisons. Moreover, we anticipate that measurement errors in the underlying prices will affect the results more than any differences in the weights, which are R\&D- and industryspecific. $^{24}$

\section{Alternative versions of the $R \& D P P P$ at the country level, 1997}

Table 9 reports the different versions of relative price levels based on various R\&D PPPs, labeled (a) through (c), and the alternative (d), the GDP PPP which is used in current practice. As discussed above, these alternatives make different assumptions about what prices to use to represent non-labor R\&D input prices. The price levels based on the alternative R\&D PPPs (b) and (c) are quite similar to the one using our preferred R\&D PPP (a). They differ by -7.1 to +1.8 percentage points from the preferred specification (a) for each country. Alternative R\&D PPP (b)

\footnotetext{
${ }^{24}$ The issue of measurement errors in international pricing programs, such as the ICP program or the ICOP project, is discussed extensively elsewhere. For a discussion of measurement issues related to the expenditure-based ICP program, see the "Castles report" (OECD, 1997). For a review of industry-of-origin studies of PPPs and productivity, see van Ark (1993) and van Ark and Timmer (2001).
} 
"lab+mat+GDP" yields results that are within 5 percentage points of the preferred R\&D PPP (a), while alternative (c) "lab+GDP" yields results within about 7 percentage points of (a). Recall that both alternatives (b) and (c) are based on a Griliches-Jaffe type R\&D PPP. In particular alternative (c) is relatively straightforward to compute, since it only requires a PPP for R\&D labor and a GDP PPP.

\section{[Table 9 about here]}

In sharp contrast, the current practice of using the GDP PPP by itself yields substantially different results from the preferred measure. Compared to the preferred R\&D PPP (a), current practice version (d) varies by 12.4 percentage points on average and by as much as 20.6 percentage points in the case of Japan. Only for Germany are the results within the range of the other alternatives. The size of these differences suggests that the use of an R\&D PPP will yield comparative costs and R\&D intensities that vary substantially from the current practice of using GDP PPPs, likely increasing the real R\&D performance of the comparison countries relative to the United States.

\section{Alternative R\&D PPPs at the industry level, 1997}

When comparing the preferred R\&D PPP (a) with alternative (b) that uses fully industryspecific input price data at the level of individual industries, the coefficients of variation across industries are about the same for both R\&D PPP versions, and we see similar significant differences across industries and countries under an ANOVA analysis. The price levels are significantly determined by the price of R\&D labor, which both preferred version (a) and alternative (b) contain in equal proportions. Therefore, it is not surprising that the simple correlation between the two sets of price levels (a) and (b) is 0.83 . If we correlate the industryspecific prices with GDP PPPs by themselves, the correlation is only about 0.59 .

These results suggest that it is important that the R\&D PPP be industry-specific, but that it is less essential that a full R\&D PPP be developed for all input categories in a specific year. Given the current uncertainties in measurement of the R\&D PPP for other current cost and capital expenditure, the alternatives (b) and (c) that combine R\&D-specific measures of the price

of labor (and preferably also material prices) with output prices performs very similarly to a fully 
developed R\&D PPP. These results are consistent with analogous findings about the importance of measuring R\&D labor prices in the time dimension, in studies by Mansfield (1987) and Jankowski (1993).

\section{Alternative versions of the $R \& D P P P, 1987$}

In order to assess how much the 1987 R\&D-specific PPPs differ from the current practice of using the GDP PPP as a substitute, we also compared the preferred R\&D PPP and several alternatives with the GDP PPP, just as we did for the 1997 PPPs. $^{25}$ Again the alternative R\&D PPPs are quite similar to the preferred R\&D PPP. The alternative PPPs for the European countries differ by no more than 7 percentage points from the preferred PPPs. The gap for Japan is somewhat larger with R\&D PPP alternative (c) "lab+GDP" differing by 17 percentage points from the preferred PPP. However, for all countries, the GDP PPP (d) yields quite different results from any of the other measures. As with the 1997 values, there is substantial variation across industries and great similarity in the coefficients of variation between R\&D PPP versions (a) and (b). Arguably, alternative (a) is too difficult to calculate systematically on a year-by-year basis, but it is relatively straightforward to obtain (b) and in particular (c), and these alternatives provide $R \& D$ price levels that correspond reasonably close to the preferred ones. We will return to this issue in our closing comments.

\subsection{Comparing the distribution of relative prices over time}

Having made two benchmark estimates, it is tempting to use them to compare the change in relative price levels of each country vis-à-vis the United States over time. In principle, such comparison should give more reliable results, since even though the relative price levels are measured with some error in each benchmark year, they tend to cancel out for measures of change over time provided the errors come from the same sources in each year. Such an argument is often invoked in the context of discussions of productivity growth estimates (for example, Hulten 2001). However, even when basic price and quantity data for the benchmark PPPs and time series are consistent, two index number problems plague a comparison of PPPs for two different benchmark years. The first problem is that for a comparison between two points in time the weights need to be held fixed. The second element relates to the fact that the time

\footnotetext{
${ }^{25}$ See McGuckin et al. (2004a), table A4.
} 
series are typically based on national weights of each individual country, whereas benchmark estimates are based on a common weighting system for both countries. Both weighting problems are well-known in the price-index number literature, and have been called the "tableau effect" by Heston and Summers (1991). ${ }^{26}$

Despite these difficulties, it is informative to compare the change in our R\&D PPPs between 1987 and 1997 to the change in GDP PPPs over the same period. While the period considered is relatively short and the levels of development across countries are not too different, comparisons of PPP results from two different benchmark years will only lead to relatively minor inconsistencies when price and quantity structures remain rather stable.

\section{[Table 10 about here]}

In Table 10 we show the change in the R\&D PPPs for total manufacturing for the preferred construction, alternative (b) "lab+mat+GDP" PPPs and the change in the GDP PPPs. ${ }^{27}$ The table shows that while the sign of the change in the PPPs is the same for each alternative PPP, the magnitudes differ considerably, even between our preferred measure (a) and alternative (b). But on average the difference between the two R\&D PPPs is smaller than the difference between the R\&D PPPs and the GDP PPPs. These results suggest that the current practice of using GDP PPPs over time will be biased compared to using dedicated R\&D PPPs, with the direction of the bias varying by country and industry. In addition it calls into question using GDP deflators to compare R\&D expenditure over time as suggested by Jankowski (1993) on the basis of U.S. data that are now over 10 years old. These results suggest that the development of dedicated R\&D deflators could be worthwhile.

\section{Real $R \& D$ intensities}

As mentioned in the introductory section, the ratios of R\&D expenditure to GDP or national income are a key focus of policy discussions across the world, and are often used as comparative measures of the intensity of the efforts devoted to innovative activities. Since such

\footnotetext{
${ }^{26}$ Conceivably, an appropriate weighting system should exist (something akin to chain-weighting or so-called "spanning trees") that could remedy these inconsistencies, but an exploration of this issue is beyond the scope of this paper. See, for example, Hill (2004).
} 
comparisons of $\mathrm{R} \& \mathrm{D}$ intensities often rely on nominal figures to make comparisons, this is an application where properly adjusting for price differences may have a substantial impact. We therefore examine the effect on $R \& D$ intensities of adjusting for differences in $R \& D$ prices as well as output prices at the level of total manufacturing and for individual industries. While we cannot directly apply the R\&D PPPs we develop in this study to economy-wide R\&D - since the non-manufacturing R\&D could be quite different and almost $36 \%$ of private U.S. R\&D was outside of manufacturing in 1999 - the differences between nominal and real R\&D intensities that we observe should be indicative of the dangers that may exist with current practice for similar measures covering the aggregate economy.

\subsection{Adjusting R\&D intensities for differences in price structure}

Real R\&D intensity measures require that R\&D expenditure be deflated by an R\&D PPP, and output by an appropriate output PPP. In this paper we have developed preferred and alternative R\&D PPPs. Here we use the preferred one. For output, the PPPs come from industryof-origin studies conducted in the International Comparisons of Output and Productivity (ICOP) project at the University of Groningen. These output PPPs, or more appropriately unit value ratios (UVRs), are calculated using data on quantities and values of output from production censuses and industrial surveys. Individual products are matched across countries and then weighted to form industry-specific and - after aggregation - manufacturing-wide PPPs. ${ }^{28}$

\section{Quality adjustments for output PPPs}

As with all price measurement, adequately taking into account the differences and changes in quality of products is a difficult undertaking. Moreover, as with other price indexes, research on quality adjustment has generally focused on comparing constant-quality prices over time, rather than constant-quality prices across countries. ${ }^{29}$ Exceptions are the work of Danzon and Chao (2000), Konijn, Moch and Dalén (2003) and van Mulligen (2003). Danzon and Chao

\footnotetext{
${ }^{27}$ We do not show changes in relative price levels here since those include both changes in the PPPs and changes in exchange rates and are therefore more difficult to interpret.

${ }^{28}$ For a more extensive general description of this method, see - van Ark (1993) and van Ark and Timmer (2001). For the European manufacturing UVRs PPPs used in this study, see O'Mahony and van Ark (2003). For the JapanU.S. PPPs, see Inklaar, Wu and van Ark (2003). Aggregation follows similar procedures as described earlier in the case of R\&D PPPs.

${ }^{29}$ For a survey of quality change over time for non-R\&D products, see Lebow and Rudd (2003). For literature on cross-country quality measurement, see van Ark (1993) and van Mulligen (2003).
} 
(2000) estimate PPPs for pharmaceuticals, Konijn et al. (2003) estimate computer PPPs and van Mulligen (2003) estimates automobile PPPs. Of these studies only the work of van Mulligen (2003) fits well into the industry-of-origin approach, since it compares prices of cars that are produced in a country. The other two studies examine the bundle of goods purchased in that country.

For our output PPPs, we therefore only make use of the automobile PPPs constructed by van Mulligen (2003). The main difference with standard UVRs based on the (producer) unit value per average car is that these PPPs take into account the fact that cars produced in the United States generally have more horsepower and are larger than those produced in Europe or Japan. Van Mulligen uses power and length characteristics of vehicle models to estimate qualityadjusted PPPs using hedonic methods. Unadjusted conversion factors are shown to be biased downward by as much as $50 \%$ relative to the United States.

It is much harder to gauge what the likely effects would be of quality-adjusted PPPs for other products such as computers or telecom equipment. A complicating factor is that many of these high-tech goods are not produced in all countries. In a series of comparisons of productivity for manufacturing industries by the McKinsey Global Institute, quality adjustments were made on an industry-by-industry basis mostly on the basis of proprietary information or by using expert judgments on the quality of comparable products (McKinsey Global Institute, 1993; Gersbach and van Ark, 1994). Although quality adjustments could be considerable for particular products, we have not used this information, as it is only available for a limited number of industries, relating to the early 1990s and covering only Germany, Japan and the United States. ${ }^{30}$

\section{Real $R \& D$ intensities and ranking}

The nominal and real $R \& D$ intensities at the level of total manufacturing are shown in Table 11, for 1987 and 1997. The nominal R\&D intensity is in the first column, the real R\&D intensity in the second, and the difference between the real and the nominal intensities in the

\footnotetext{
${ }^{30}$ For example, for personal computers the different composition of products produced in Germany and the United States led to an upward adjustment of the census-based German/U.S. computer output PPP by $41 \%$ in 1990 . The PPP for audio and video equipment (including telecom equipment) was only adjusted upwards by 5.1\%. At more aggregate levels (e.g. for total manufacturing) these effects are likely to be much smaller as quality adjustments for some other industries may bias the PPP in the opposite direction (Gersbach and van Ark, 1994).
} 
third. ${ }^{31}$ The real R\&D intensity is calculated by using R\&D PPPs to deflate nominal R\&D expenditure and using output PPPs to convert manufacturing gross output to a common currency. The difference between the real and nominal intensities can therefore be traced to these two adjustments.

\section{[Table 11 about here]}

In Table 11 the nominal $R \& D$ intensity is defined as manufacturing $R \& D$ expenditure divided by manufacturing gross output, as gross output is the correct measure for sectoral analysis. Since international comparisons often are made using GDP, we also replicated all the analysis using R\&D intensities based on value added as the output measure. Table B21 in McGuckin et al. (2004a) shows these results. The magnitude of the value added-based intensities is roughly three times higher because the value added measure omits intermediate inputs. The main results of the analysis, reported below, are the same irrespective of the output measure used.

The U.S. R\&D intensity is highest in all cases, even after the PPP adjustments described above. The typical adjustment, using R\&D and output PPPs, to each of the comparison countries is positive and sizable, yielding R\&D intensities that are closer to the U.S. level than under current practice and this is true for both 1987 and $1997 .{ }^{32}$ These results suggest that the efforts devoted to $R \& D$ in each country are more similar across countries than is apparent using the nominal $R \& D$ intensities that are currently the norm.

The effect of the price adjustments on $R \& D$ intensity is particularly large for the United Kingdom: before adjustment (in nominal terms), its R\&D intensity is only $2.1 \%$ in 1987 and $1.9 \%$ in 1997. After adjustment for relative prices of R\&D and gross output, the U.K.'s R\&D intensity (in real terms) is much higher at 3.1\% in 1987 and 2.5\% in 1997. In 1987, these adjustments shift the rank of the U.K. from next-to-last among the six countries in this study to second place after the United States, displacing Germany and Japan. The R\&D PPP contributed about two-thirds of the adjustment in that year.

\footnotetext{
${ }^{31}$ The results described here are based on the preferred R\&D PPP. If the alternative R\&D PPP is used instead of the preferred R\&D PPP, the difference between the nominal and real $R \& D$ intensities is similar and the changes in rank are identical.

${ }^{32}$ Since the United States is the base country, the U.S. intensity does not change with the PPP adjustment.
} 
Not only are the levels of R\&D intensity affected by price adjustments, but so are the changes in R\&D intensity. From 1987 to 1997, nominal R\&D intensity in Germany dropped by 0.2 percentage points. Using real R\&D intensity, however, the drop was 0.4 points. In general, R\&D PPPs declined less than output PPPs, worsening the trend in R\&D intensity between 1987 and 1997.

\section{Real $R \& D$ intensities for individual industries}

R\&D intensities for individual industries are subject to the same interpretation problems as those at more aggregate levels due to the use of nominal values. Using industry-specific $R \& D$ PPP and output PPP price adjustments to adjust nominal industry-level R\&D intensities gives real $R \& D$ intensities for individual industries. As a result of the large variation in the R\&D PPPs (because of large R\&D labor price variation), output PPPs, and nominal R\&D intensities across industries, these adjustments are often larger in percentage points than those at the total manufacturing level. The average difference between real (PPP adjusted) R\&D intensities and nominal R\&D intensities is 0.7 percentage point at the industry level, while for total manufacturing this is only 0.3 percentage points.

A key question for the interpretation of these differences is how important the adjustment for differences in relative $R \& D$ and output prices is compared to the differences in nominal $R \& D$ intensity. A two-way ANOVA between real and nominal R\&D intensity among the six countries and 19 industries demonstrates that the variation among industries is very large and statistically significant, while differences across countries are relatively small, and not statistically significant. The variation among industries is likely attributable to the differences in technologies and $R \& D$ production functions and to demand-side opportunities that generate differences in the intensity of R\&D efforts across industries. The smaller differences across countries are most likely a result of internationalization of $R \& D$ and increased competitiveness due to globalization.

\section{Concluding Comments}

This paper develops R\&D PPPs that are conceptually appropriate in that they are based on relative prices for a basket of R\&D inputs. To the extent that current data allows, we have developed R\&D-specific prices and weights and aggregated them into R\&D PPPs for 19 individual manufacturing industries covering the years 1997 and 1987. Previous R\&D PPP estimates did not utilize such detailed R\&D-specific price and weight data as in this study, nor 
did they use interviews to guide the application of their methodology. Thus the R\&D PPPs we developed allow us to better evaluate the importance of having $R \& D$-specific measures of $R \& D$ price across countries.

A comparison of our preferred R\&D PPPs with GDP PPPs suggests that current procedures for comparing $\mathrm{R} \& \mathrm{D}$ across countries are flawed. While there is some netting of industry differences at the economy-wide level, the GDP PPPs still differ substantially from R\&D PPPs. At the industry level, use of the GDP PPP as a proxy for the R\&D PPP is inappropriate. The differences between R\&D PPPs and GDP PPPs are large and a substantial fraction of these differences can be traced to variations in the price of R\&D labor across industries.

The size of this difference and the relatively complex nature of our preferred R\&D PPP has led us to consider two alternatives that can be readily calculated and could easily be adopted by statistical agencies. These relatively easy-to-measure alternative R\&D PPPs are based on a Griliches-Jaffe type index and are relatively close to the preferred R\&D PPP in approximating differences in $R \& D$ price across countries and industries. The most plausible alternative measure combines industry-specific R\&D labor PPPs and industry output PPPs for materials and supplies with the GDP PPP for other inputs.

While the most important source of differences at the economy-wide level is still R\&D labor cost, prices of the other inputs to R\&D can and do vary across industries. So by advocating that priority needs to be given to develop labor PPPs, we are not suggesting that price measurement for other inputs to R\&D should be ignored. For comparisons over time, few substitutes for our preferred R\&D PPP are available. While industry-level changes in the preferred R\&D PPP over time correlate well with those of the alternative R\&D PPPs, differences at the total manufacturing level are large enough to cause significant errors of interpretation in not only R\&D expenditures, but also R\&D intensities. This suggests that periodic benchmark estimates of the preferred R\&D PPP would be useful to ensure that an alternative R\&D PPP that relies mainly upon variations in R\&D labor prices maintains a solid grounding over time.

Our results in the interspatial domain also suggest that intertemporal R\&D deflator work should be given further attention. We find important differences between changes in the GDP PPP and the R\&D PPPs. While one cannot draw direct conclusions regarding the development of relative prices due to different weighting systems at varying points in time, the results suggest 
that it would be useful to reexamine Jankowski's (1993) finding of a correlation between the GDP and the R\&D deflator. One reason is that his study is now over 10 years old and there have been vast changes in economic structure and measurement of quality change. There is also evidence that this correlation does not hold up as well in other countries. ${ }^{33}$ Moreover, given the lack of strong conceptual roots in using GDP as a measure of R\&D price, internationally consistent R\&D deflators should be further examined in the time domain.

Finally, we consider it vital that research be continued in this area. Our study is the first to examine R\&D PPPs at the industry level, and the only study that has been able to take advantage of the recently developed measures of comparable prices at the output level from the University of Groningen's ICOP program. Further improvements in price measurement and ongoing harmonization of R\&D statistics and survey instruments could facilitate the construction of future comparisons, and render them more reliable. Rapid growth of global R\&D activities makes it vital that accurate comparisons be made of $\mathrm{R} \& \mathrm{D}$, regardless of where it is performed.

\section{References}

Bernstein, J. (1986), Price Indexes for Canadian Industrial Research and Development Expenditures, Montreal: Statistics Canada.

Brunner, E.D. (1967), The Cost of Basic Scientific Research in Europe: Department of Defense Experience, 1955-1966, Report for United States Air Force Project, Santa Monica: RAND. Cameron, G. (1996), “On the Measurement of Real R\&D: Divisia Price Indexes for U.K. Business Enterprise R\&D," Research Evaluation 6 (3): 215-19.

The Conference Board (1976), Overseas Research and Development by United States

Multinationals, 1965-1975: Estimates of Expenditures and A Statistical Profile, New York: The Conference Board.

Danzon, P.M. and Chao, L.W. (2000), “Cross-national price differences for pharmaceuticals: how large, and why?" Journal of Health Economics, 19: 159-195.

DiMasi, J.A., R.W. Hansen, and H.G. Grawbowski (2003), “The price of innovation: new estimates of drug development costs," Journal of Health Economics 22: 151-185.

\footnotetext{
${ }^{33}$ For instance, Bernstein (1986) found that the GDP price deflator did not correspond well with an input-based R\&D price deflator for Canada. Cameron (1996) found a similar result for the United Kingdom.
} 
European Commission (2002), Presidency Conclusions - Barcelona European Council, available at http://europa.eu/european_council/conclusions/index_en.htm.

Fraumeni, B. and S. Okubo (2005), "R\&D in the National Income and Product Accounts: A First Look at its Effect on GDP," in C. Corrado, J. Haltiwanger and D. Sichel (eds) Measuring Capital in the New Economy, Studies in Income and Wealth, Volume 65, Chicago: University of Chicago Press.

Freeman, C. and A. Young (1965), The Research and Development Effort in Western Europe, North America and the Soviet Union: An Experimental International Comparison of Research Expenditures and Manpower in 1962, Paris: Organization for Economic Cooperation and Development (OECD).

Gersbach, H. and B. van Ark (1994), "Micro Foundations for International Productivity Comparisons", Research Memorandum GD-11, Groningen Growth and Development Centre. Griliches, Z. (1984), R\&D, Patents, and Productivity, National Bureau of Economic Research, Cambridge, MA: University of Chicago Press. (1994), "Productivity, R\&D and the Data Constraint," American Economic Review Papers and Proceedings 84(1): 1-23.

Heston, A. and Summers, R. (1991), “The Penn World Table (Mark 5): An Expanded Set of International Comparisons, 1950-1988," Quarterly Journal of Economics, 106(2): 327-68, May. (1996), "International price and quantity comparisons: potentials and pitfalls," American Economic Review, (86) 2: 20-24, May.

Hill, R. (2004), "Constructing Price Indexes Across Space and Time: The Case of the European Union," The American Economic Review, 94(5): 1379-1410.

Hulten, C.R. (2001), “Total Factor Productivity: A Short Biography,” in C.R. Hulten, E.R. Dean, and M.J. Harper, eds., New Developments in Productivity Analysis, Studies in Income and Wealth, Volume 63, Chicago: University of Chicago Press, pp. 1-47.

Inklaar, R., Wu, H.X., and van Ark, B. (2003), "Losing Ground: Japanese Labour Productivity and Unit Labour Cost in Manufacturing in Comparison to the U.S.," Groningen Growth and Development Centre Research Memorandum, no. 64, available at http://www.ggdc.net/pub/gd64.shtml. 
Jankowski, J.E. (1993), “Do we need a price index for industrial R\&D?” Research Policy 22: 195-205.

Jaffe, S.A. (1972), A Price Index for Deflation of Academic R\&D Expenditures, NSF 72-310, U.S. Government Printing Office, Washington, DC: National Science Foundation.

Jorgenson, D. and M. Kuroda (1992), "Productivity and International Competitiveness in Japan and the U.S., 1960-1985", Economic Studies Quarterly 43(2): 313-25.

Kiba, T., Sakuma, I. and Kikuchi, J. (1994), "Development of R\&D Purchasing Power Parities," National Institute of Science and Technology Policy (NISTEP), Report No. 31, Tokyo, Japan, available at http://www.nistep.go.jp/achiev/ftx/eng/rep031e/text/rep031e.txt.

Konijn, P., Moch, D. and Dalén, J. (2003), "Comparison of hedonic functions for PCs across E.U. countries,” Discussion Paper, Eurostat, available at http://www.ifcommittee.org/konijn.pdf.

Kravis, I., Heston, A. and Summers, R. (1982), World Product and Income: International Comparisons of Real Gross Product, Baltimore: The Johns Hopkins University Press.

Lebow, D.E. and Rudd, J.B. (2003), "Measurement Error in the Consumer Price Index: Where Do We Stand?" Journal of Economic Literature, 41(1): 159-201, March.

MacDonald, A.S. (1973), "Exchange Rates for National Expenditure on Research and Development," The Economic Journal 83(330): 476-494, June.

Mansfield, E. (1987), “Price Indexes for R\&D Inputs, 1969-1983,” Management Science 33(1): 124-29.

(1988), "The Speed and Cost of Industrial Innovation in Japan and the U.S.: External vs. Internal Technology," Management Science 34(10): 1157-68.

McGuckin, R.H., van Ark, B., Dougherty, S.M., and Inklaar, R.C. (2004a), Appendices to the Report on Internationally Comparable Science, Technology, and Competitiveness Indicators (revised), National Science Foundation SRS00-99594, available at http://www.conferenceboard.org/economics/workingpapers.cfm.

McGuckin, R.H., Inklaar, R.C., van Ark, B., Dougherty, S.M. (2004b) "The Structure of Business R\&D: Recent Trends and Measurement Implications", Economics Program Working Paper, New York, available at http://www.conference-board.org/economics/workingpapers.cfm. McKinsey Global Institute (1993), Manufacturing Productivity, Washington: McKinsey \& Co. 
Mulligen, P.H. van (2003), Quality aspects in price indices and international comparisons: Applications of the hedonic method, Statistics Netherlands: Voorburg.

National Science Foundation (1998), The Science and Technology Resources of Japan: A Comparison with the United States, Special Report, NSF 96-324, by Jean M. Johnson (Arlington, VA, 1997), available at http://www.nsf.gov/sbe/srs/nsf97324/start.htm. (2002), Science and Engineering Indicators, Washington, D.C.

OECD (1979), "Price Indexes and R\&D Exchange Rates" in Trends in Industrial $R \& D$ in Selected Member Countries: 1966-1975, Paris: OECD, pp. 158-169. (1963, 1981, 1994, 2002), Frascati Manual-Standard Practice for Surveys of Research and Experimental Development. The Measurement of Scientific and Technological Activities Series, $1^{\text {st }}, 4^{\text {th }}, 5^{\text {th }}$, and $6^{\text {th }}$ editions, Paris: OECD.

OECD (1997), "Review of the OECD-Eurostat PPP Program", Paris, available at http://www.oecd.org/std/ppp/pps.htm. (2002), PPPs and Real Expenditures 1999 Benchmark Year, Paris: OECD. (2003), Research and Development Statistics: 2003 edition, Paris: OECD. (2004), STructural ANalysis (STAN) Database, Paris: OECD.

O'Mahony, M. and B. van Ark (2003), eds., E.U. Productivity and Competitiveness: An Industry Perspective; Can Europe Resume the Catching-Up Process?, available at http://www.ggdc.net/pub/EU_Productivity_and_Competitiveness.shtml van Ark, B. (1993), International Comparisons of Output and Productivity, Monograph Series No. 1, Groningen Growth and Development Centre, available at http://www.ggdc.net/pub/arkbook.shtml. , and Timmer, M.P. (2001), "PPPs and International Productivity Comparisons: Bottlenecks and New Directions", Paper presented at the World Bank-OECD Seminar on Purchasing Power Parities: Recent Advances in Methods and Applications, Washington, D.C., available at http://www.oecd.org/dataoecd/24/0/2424747.pdf. 
TABLE 1

Previous studies of R\&D PPPs -- R\&D price levels (cost relative to the U.S.)*

\begin{tabular}{|c|c|c|c|c|c|}
\hline Country & $\begin{array}{c}\text { Freeman \& Young } \\
1962 \\
\end{array}$ & $\begin{array}{c}\text { Brunner }^{* *} \\
1961-2 \\
\end{array}$ & $\begin{array}{c}\text { MacDonald }^{* \star *} \\
1963-4 \\
\end{array}$ & $\begin{array}{c}\text { OECD } \\
1970 \\
\end{array}$ & $\begin{array}{c}\text { Kiba et al. } \\
1985\end{array}$ \\
\hline France & 66.7 & 42.4 & 60.0 & 73.3 & 76.8 \\
\hline Germany & 58.8 & 28.7 & 60.0 & 70.6 & 85.4 \\
\hline Japan & - & - & 35.3 & 57.1 & 81.3 \\
\hline Netherlands & 52.6 & - & 66.7 & 68.1 & - \\
\hline U.K. & 55.6 & 34.0 & 60.0 & 58.8 & 68.0 \\
\hline U.S. & 100.0 & 100.0 & 100.0 & 100.0 & 100.0 \\
\hline
\end{tabular}

${ }^{*} R \& D$ price levels are defined as $R \& D$ purchasing power parity (PPP) divided by the exchange rate of the country's currency relative to the U.S. dollar. These levels represent costs relative to the United States. ${ }^{* *}$ Refers to research costs only. ${ }^{* *}$ Price levels are converted to use the U.S. as base country (original study used the U.K. as base country).

Sources: Freeman and Young (1965), Brunner (1967), MacDonald (1973), OECD (1979) and Kiba, Sakuma and Kikuchi (1994).

\section{TABLE 2}

R\&D PPP input categories and price measures

\begin{tabular}{|c|c|c|c|c|}
\hline \multirow{2}{*}{$\begin{array}{l}\text { R\&D input } \\
\text { category }\end{array}$} & \multicolumn{2}{|l|}{ Input prices } & \multirow{2}{*}{$\begin{array}{l}\text { Industry- } \\
\text { specific? }\end{array}$} & \multirow{2}{*}{$\begin{array}{c}\text { Avg. } \\
\text { weight }\end{array}$} \\
\hline & Measure & Source & & \\
\hline 1. Labor compensation & Average wages for $R \& D$ personnel & NSF/OECD & Yes & $49 \%$ \\
\hline 2. Materials and supplies & Price of industry's output adj. for margins & ICOP & Yes & $18 \%$ \\
\hline 3. Other current costs & Prices of overhead goods and services & ICOP/ICP & No & $24 \%$ \\
\hline 4. Capital expenditure & Prices of plant and equipment & ICOP/ICP & No & $9 \%$ \\
\hline Total R\&D* & & & Yes & $100 \%$ \\
\hline
\end{tabular}

${ }^{*}$ Aggregation of $R \& D$ input category prices to total $R \& D$ uses $R \& D$ expenditure weights from national $R \& D$ surveys. $I C O P=$ International Comparisons of Output and Productivity Project, University of Groningen $I C P=$ International Comparisons Project (United Nations, World Bank, Eurostat, OECD)

Sources: NSF (2002), OECD (2002, 2003), ICOP 1997: O'Mahony and van Ark (2003) and Inklaar et al. (2003), ICOP 1987: van Ark (1993)

\section{TABLE 3}

R\&D expenditure shares, total manufacturing, 1997

\begin{tabular}{|c|c|c|c|c|c|c|c|}
\hline \multirow{2}{*}{$\begin{array}{l}\text { R\&D input } \\
\text { category }\end{array}$} & \multicolumn{6}{|c|}{ Shares of total manufacturing R\&D expenditure } & \multirow{2}{*}{$\begin{array}{l}\text { Average from } \\
\text { Interviews }\end{array}$} \\
\hline & France & Germany & Japan & Netherlands & U.K. & U.S. & \\
\hline 1. Labor compensation & $52.8 \%$ & $61.7 \%$ & $42.7 \%$ & $52.1 \%$ & $37.0 \%$ & $46.5 \%$ & $46.7 \%$ \\
\hline 2. Materials and supplies & $16.9 \%{ }^{*}$ & $13.9 \%$ * & $20.3 \%$ & $14.7 \% *$ & $26.1 \%$ & $15.8 \%$ & $19.7 \%$ \\
\hline 3. Other current costs & $23.2 \%$ & $17.5 \%$ & $27.3 \%$ & $23.7 \%$ & $24.8 \%$ & $29.3 \%$ & $24.4 \%$ \\
\hline 4. Capital expenditure & $7.1 \%$ & $6.9 \%$ & $9.7 \%$ & $9.5 \%$ & $12.1 \%$ & $8.4 \%$ * & $9.2 \%$ \\
\hline Total R\&D cost & $100.0 \%$ & $100.0 \%$ & $100.0 \%$ & $100.0 \%$ & $100.0 \%$ & $100.0 \%$ & $100.0 \%$ \\
\hline
\end{tabular}

*See text for description of assumptions made to determine weights.

${ }^{*}$ Average of 10 firms' expenditures that provided detailed financial data for total R\&D in interviews.

See McGuckin et al. (2004a) for more details.

Source: National R\&D surveys, NSF (2002), OECD (2003) 
TABLE 4

R\&D PPPs and R\&D price levels (cost relative to the U.S.), total manufacturing., 1997

\begin{tabular}{lcccccc}
\hline & $\begin{array}{c}\text { France } \\
€ / \$\end{array}$ & $\begin{array}{c}\text { Germany } \\
€ / \$\end{array}$ & $\begin{array}{c}\text { Japan } \\
\end{array}$ & $\begin{array}{c}\text { Netherlands } \\
€ / \$\end{array}$ & $\begin{array}{c}\text { U.K. } \\
£ / \$\end{array}$ & $\begin{array}{c}\text { U.S. } \\
\$ / \$\end{array}$ \\
\hline \hline R\&D (lab+mat+OC+cap): & 0.86 & 0.98 & 138.1 & 0.80 & 0.54 & 1.00 \\
Exchange rates: & 0.89 & 0.88 & 121.0 & 0.88 & 0.61 & 1.00 \\
R\&D price level (U.S.=100):** & 96.4 & 111.0 & 114.1 & 90.0 & 88.8 & 100.0 \\
\hline \hline
\end{tabular}

${ }^{*}$ Exchange rates are year-averages (EMU countries converted into Euro equivalents);

${ }^{* *} R \& D$ price levels are defined as $R \& D$ purchasing power parity $(P P P)$ divided by the exchange rate of the country's currency relative to the U.S. dollar. These levels represent costs relative to the United States.

Sources: see sources Table 2 and 3

TABLE 5

R\&D input price levels (cost relative to the U.S.), total manufacturing, 1997

\begin{tabular}{lcccccc}
\hline Input category & France & Germany & Japan & Netherlands & U.K. & U.S. \\
\hline \hline 1. Labor compensation & 84.9 & 97.6 & 93.9 & 76.4 & 58.9 & 100.0 \\
2. Materials and supplies & 118.1 & 129.9 & 101.0 & 117.5 & 149.3 & 100.0 \\
3. Other current costs & 102.0 & 133.2 & 161.3 & 95.0 & 107.1 & 100.0 \\
4. Capital expenditure & 108.8 & 119.1 & 103.3 & 118.4 & 105.2 & 100.0 \\
\hline \hline
\end{tabular}

Note: $R \& D$ price levels are defined as $R \& D$ purchasing power parity $(P P P)$ divided by the exchange rate of the country's currency relative to the U.S. dollar. These levels represent costs relative to the United States.

Sources: see sources Table 2 and 3

TABLE 6

R\&D PPPs and R\&D price levels (cost relative to the U.S.), total $\mathrm{mfg}_{.,}, 1987$

\begin{tabular}{lcccccc}
\hline & $\begin{array}{c}\text { France } \\
€ / \$\end{array}$ & $\begin{array}{c}\text { Germany } \\
€ / \$\end{array}$ & $\begin{array}{c}\text { Japan } \\
¥ / \$\end{array}$ & $\begin{array}{c}\text { Netherlands } \\
€ / \$\end{array}$ & $\begin{array}{c}\text { U.K. } \\
£ / \$\end{array}$ & $\begin{array}{c}\text { U.S. } \\
\$ / \$\end{array}$ \\
\hline \hline R\&D (lab+mat+OC+cap): & 0.99 & 1.06 & 141.1 & 0.97 & 0.48 & 1.00 \\
Exchange rates:* $_{\text {R\&D price level (U.S.=100):** }}$ & 0.92 & 0.92 & 144.6 & 0.92 & 0.61 & 1.00 \\
\hline \hline
\end{tabular}

${ }^{\star}$ Exchange rates are year-averages (EMU countries converted into Euro equivalents);

${ }^{* *} R \& D$ price levels are defined as $R \& D$ purchasing power parity (PPP) divided by the exchange rate of the country's currency relative to the U.S. dollar. These levels represent costs relative to the United States.

Sources: see sources Table 2 and 3 and McGuckin et al. (2004a)

TABLE 7

R\&D input price levels (cost relative to the U.S.), total manufacturing, 1987

\begin{tabular}{lcccccc}
\hline Input category & France & Germany & Japan & Netherlands & U.K. & U.S. \\
\hline \hline 1. Labor compensation & 92.0 & 110.8 & 83.1 & 89.7 & 48.4 & 100.0 \\
2. Materials and supplies & 128.3 & 121.9 & 100.4 & 112.5 & 111.2 & 100.0 \\
3. Other current costs & 118.5 & 121.5 & 116.2 & 114.1 & 104.5 & 100.0 \\
4. Capital expenditure & 129.9 & 125.2 & 102.3 & 141.9 & 115.3 & 100.0 \\
\hline \hline
\end{tabular}

Note: $R \& D$ price levels are defined as $R \& D$ purchasing power parity $(P P P)$ divided by the exchange rate of the country's currency relative to the U.S. dollar. These levels represent costs relative to the United States.

Sources: see sources Table 2 and 3 and McGuckin et al. (2004a) 
TABLE 8

Selection of input price measures for alternative versions of R\&D PPP, by input category

\begin{tabular}{|c|c|c|c|c|}
\hline \multirow{2}{*}{$\begin{array}{l}\text { R\&D input } \\
\text { category }\end{array}$} & \multicolumn{4}{|c|}{ Price measure } \\
\hline & Preferred (a) & Alternative (b) & Alternative (c) & Current Practice (d) \\
\hline \multirow{3}{*}{$\begin{array}{l}\text { 1. Labor compensation } \\
\text { 2. Materials and supplies } \\
\text { 3. Other current costs } \\
\text { 4. Capital expenditure }\end{array}$} & \multirow{3}{*}{$\begin{array}{c}\text { Labor } \\
\text { Materials } \\
\text { Other current } \\
\text { Capital } \\
\end{array}$} & Labor price parity & Labor price parity & \multirow{3}{*}{ GDP PPP* } \\
\hline & & Materials price parity & \multirow[b]{2}{*}{ GDP PPP* } & \\
\hline & & GDP PPP* & & \\
\hline
\end{tabular}

Notes: Price parity is price of good in comparison country divided by price of same good in base country (U.S.);

The labor price parity and materials price parity are available at the level of specific industries. ${ }^{*}$ Categories with the same price measure use the total weight of the merged categories for R\&D PPP aggregation.

TABLE 9

Comparison of price levels (cost relative to the U.S.) using preferred R\&D PPPs and alternative R\&D PPPs, total manufacturing, 1997

\begin{tabular}{lcccccc}
\hline R\&D PPP Version & France & Germany & Japan & Netherlands & U.K. & U.S. \\
\hline $\begin{array}{l}\text { Preferred } \\
\text { (a) R\&D (lab+mat+OC+cap) }\end{array}$ & 96.4 & 111.0 & 114.1 & 90.0 & 88.8 & 100.0 \\
\hline & & & & & & \\
Alternatives: & 98.2 & 106.4 & 109.0 & 90.1 & 88.0 & 100.0 \\
(b) R\&D (lab+mat+GDP) & 97.3 & 104.1 & 114.7 & 88.0 & 81.7 & 100.0 \\
(c) R\&D (lab+GDP) & & & & & & \\
& & & & & & \\
Current practice & 111.4 & 112.3 & 134.7 & 100.9 & 103.2 & 100.0 \\
(d) GDP (GDP PPP) & & & & & & \\
& 1.8 & -4.6 & -5.1 & 0.1 & -0.7 & \\
\hline Difference between (a) and (b) & 0.9 & -6.9 & 0.6 & -2.0 & -7.1 & \\
Difference between (a) and (c) & 14.9 & 1.3 & 20.6 & 10.9 & 14.5 & \\
Difference between (a) and (d) & & & & &
\end{tabular}

Note: Alternative R\&D PPPs are described in Table 8.

Sources: see sources Table 2 and 3

TABLE 10

Changes of R\&D PPPs for total manufacturing and GDP PPPs between 1987 and 1997

\begin{tabular}{|c|c|c|c|c|c|c|c|c|c|}
\hline \multirow[b]{3}{*}{ Country } & \multicolumn{3}{|c|}{ Preferred (a) } & \multicolumn{3}{|c|}{ Alternative (b) } & \multicolumn{3}{|c|}{ Current practice $(\mathrm{d})$} \\
\hline & \multicolumn{3}{|c|}{ "lab+mat+OC+cap" } & \multicolumn{3}{|c|}{ "lab+mat+GDP" } & \multicolumn{3}{|c|}{ GDP PPP } \\
\hline & 1987 & 1997 & Chg. & 1987 & 1997 & Chg. & 1987 & 1997 & Chg. \\
\hline France & 1.02 & 0.86 & $-16.8 \%$ & 0.99 & 0.87 & $-12.4 \%$ & 1.04 & 0.99 & $-4.5 \%$ \\
\hline Germany & 1.08 & 0.98 & $-9.7 \%$ & 1.08 & 0.94 & $-14.0 \%$ & 1.13 & 0.99 & $-12.6 \%$ \\
\hline Japan & 159.1 & 138.1 & $-14.2 \%$ & 172.8 & 131.9 & $-27.0 \%$ & 210.2 & 163.0 & $-25.4 \%$ \\
\hline Netherlands & 0.95 & 0.80 & $-17.4 \%$ & 0.92 & 0.80 & $-14.5 \%$ & 1.06 & 0.89 & $-17.2 \%$ \\
\hline U.K. & 0.56 & 0.54 & $-2.8 \%$ & 0.53 & 0.54 & $1.8 \%$ & 0.56 & 0.63 & $11.1 \%$ \\
\hline U.S. & 1.00 & 1.00 & $0.0 \%$ & 1.00 & 1.00 & $0.0 \%$ & 1.00 & 1.00 & $0.0 \%$ \\
\hline
\end{tabular}

Note: Percent changes are log differences. ${ }^{*}$ Exchange rates are annual averages.

Sources: see sources Table 2 and 3 and McGuckin et al. (2004a) 
TABLE 11

Nominal and real R\&D intensity for total manufacturing (R\&D / gross output) using preferred R\&D PPP and output PPPs.

\begin{tabular}{|c|c|c|c|}
\hline \multirow[b]{2}{*}{ Country } & \multirow{2}{*}{$\begin{array}{l}\text { Current } \\
\text { practice } \\
\text { Nominal }\end{array}$} & \multicolumn{2}{|c|}{$\begin{array}{c}\text { With R\&D PPP and } \\
\text { output PPP Adjustments }\end{array}$} \\
\hline & & Real & Difference \\
\hline \multicolumn{4}{|c|}{ Year 1987} \\
\hline France & 2.06 & 2.47 & 0.42 \\
\hline Germany & 2.71 & 2.87 & 0.16 \\
\hline Japan & 2.24 & 2.75 & 0.51 \\
\hline Netherlands & 2.04 & 2.21 & 0.17 \\
\hline U.K. & 2.07 & 3.09 & 1.03 \\
\hline U.S. & 3.44 & 3.44 & 0.00 \\
\hline \multicolumn{4}{|c|}{ Year 1997} \\
\hline France & 2.22 & 2.40 & 0.18 \\
\hline Germany & 2.50 & 2.47 & -0.02 \\
\hline Japan & 2.89 & 2.95 & 0.06 \\
\hline Netherlands & 1.59 & 1.74 & 0.16 \\
\hline U.K. & 1.92 & 2.49 & 0.57 \\
\hline U.S. & 3.12 & 3.12 & 0.00 \\
\hline \multicolumn{4}{|c|}{ Change from 1987 to 1997} \\
\hline France & 0.16 & -0.07 & -0.24 \\
\hline Germany & -0.21 & -0.40 & -0.18 \\
\hline Japan & 0.65 & 0.20 & -0.45 \\
\hline Netherlands & -0.46 & -0.47 & -0.01 \\
\hline U.K. & -0.15 & -0.61 & -0.46 \\
\hline U.S. & -0.32 & -0.32 & 0.00 \\
\hline
\end{tabular}

Note: Adjustments for R\&D PPP divide R\&D expenditures by the R\&D PPP; Adjustments for Output PPP divide gross output by an Output PPP; Real intensity includes both adjustments

Sources: see sources Table 2 and 3. Gross output based on OECD (2004)

Output PPPs based on O'Mahony and van Ark (2003) and Inklaar, et al. (2003) for 1997 and van Ark (1993) for 1987. 